This paper (with supplementary material) was published by Karger as:

Rebitschek F. G., Reisel D., Lein I., \& Wegwarth O. (2019). Epigenetic risk assessment of female cancers: Women's information needs and attitudes. Public Health Genomics, 22, 46-57. doi:10.1159/000501975

\title{
Epigenetic Risk Assessment of Female Cancers: Women's Information Needs and Attitudes
}

\author{
Felix G. Rebitschek ${ }^{\mathrm{a}}$ Daniel Reisel ${ }^{\mathrm{b}}$ Ines Lein ${ }^{\mathrm{a}}$ Odette Wegwarth ${ }^{\mathrm{a}, \mathrm{c}}$

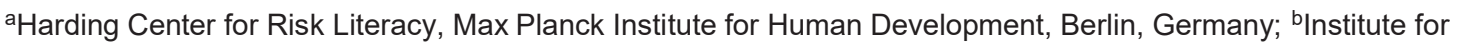 \\ Women's Health, University College London, London, UK; ' Center for Adaptive Rationality, Max Planck Institute for \\ Human Development, Berlin, Germany
}

\section{Keywords}

Epigenetic cancer risk assessment, Testing information needs, Risk testing, Focus groups

\section{Introduction}

A major goal in modern medicine is to shift from a reactive model that focuses on treatment of manifested diseases to a proactive model that focuses on prevention. For women's cancers, however, large-scale early-detection efforts have not resulted in the anticipated reduction in mortality [1]. Therefore, preventive approaches such as predicting a woman's individual cancer risk before the on- 
set of the disease are currently under development. Whereas some of these approaches are based on genetic analysis [2], more recent undertakings focus on epigenetics [3].

Epigenetic analysis comprises different physiological processes, including readouts of the methylation patterns of relevant genetic sequences. DNA methylation undergoes lifelong modification by internal (e.g., hormone system) and external (e.g., lifestyle, environment) factors. Methylation changes in breast tissue cells, however, can lead to carcinogenesis [4] and in buccal cells they can lead to mouth and throat cancer [5]. One epigenetic cancer risk assessment (ECRA) under development for female-specific cancers assesses specific changes in methylation levels in cervical epithelial cells. The premise of this research is that epigenetic changes in cervical cells might also reflect changes elsewhere in the gynaecological system. A successful test would be able to uncover risk factors for female cancers in general by using cervical cells as a surrogate.

The ECRA has a twofold aim: to motivate preventive health behaviour effectivelyand provide risk-stratified care with tangible benefits for women and health systems (precision medicine) [6]. Receiving a personalised risk estimate of developing a certain female cancer may prompt a woman to review and potentially adjust her health behaviour to reduce the risk of developing cancer. However, there is limited evidence of this at present [7, 8], which may be partly due to the fact that no study on this issue has adhered to the standards of balanced and transparent risk communication [9]. In addition, many [10] behavioural-change studies have focused on risks based on genetic testing, where results have a static nature and the potential effects of behavioural modifications are limited [11]. Epigenetic approaches are inherently dynamic and, because they are capable of showing the impact of behavioural change on the epigenome, they might be more likely to promote health behaviours.

Further, stratified care on the basis of individual cancer risks may open up the chance of personalising screening efforts: reducing participation in cancer screening if an individual is found to be at low risk or increasing if found to be at high risk [12, 13], reflecting the risk-dependent balance of the benefit-to-harm ratio [14]. Considering that physicians are often unaware of referral criteria such as women's risk status (e.g., when referring to BRCA testing) [15], women themselves have to understand the benefit-to-harm ratio of testing and of the subsequent management of care before consenting to participation [16] if ECRA is meant to be successfully implemented based on an informed choice.

Yet, informed choices about ECRA faces many hurdles that need to be addressed. Beyond the difficulties many patients have in understanding concepts in genetics [17], also many doctors struggle with correctly understanding cancer-screening statistics $[18,19]$ and other basic statistics on the benefit and harms [20], which results in a communication of risk to patients that provides invalid statistical metrics (e.g., survival rates in the context of screening) [19] and incomplete risk information (e.g., relative risks, missing reference classes) [21]. Additionally, doctors' counselling has been shown to be affected by the practice of defensive medicine (i.e., doing unnecessary test because of fear of litigation [22] and conflicts of interests [23]). All these aspects negatively affect counselling of patients that aims at an informed choice $[21,24]$ and it is reasonable to assume that they may also play a role in women's counselling on the benefits and harms of ECRA. Moreover, additional challenges for risk communication arise by predictive testing for multiple disease risks, for instance cumulative error potential of multiple estimates [25] and how to classify risk estimates in a meaningful way [26].

Given the impact of risk predictions on women's well-being and further trajectory through the health care system and the current situation of inappropriate communication of risk, health care providers need to provide transparent and balanced health communication tools. Because ECRA may specifically invite to attribute revealed risks to living conditions and past health behaviour and because it may suggest monitoring risk development over time by repeated testing, health information needs to inform about test conditions most comprehensibly. So, it needs to be developed in tandem with the potential service users in order to identify what information they would seek for and what should be prioritised [9]. Using an ECRA - currently under development by the FORECEE consortium (https://forecee.eu) - meant to inform women in the future about their baseline risks of developing any of four female cancers (breast, cervical, endometrial, and ovarian cancer), the here reported study using a focus group approach explored what information women would prefer to receive prior to testing and how they would like potential results to be communicated. Furthermore, we explored the attitudes towards the test, as understanding the underlying reasons may help tailor test communication according to patients' needs [27].

\section{Materials and Methods}

\section{Study Design, Sample, and Setting}

In four focus groups, women were instructed to discuss personal attitudes in favour of or against a hypothetical decision to participate in ECRA (including social, societal, and ethical concerns), generally desired information on ECRA, and, more spe- 
cifically, desired information on risks generated by ECRA. Because cancer risks for female cancers and care options vary between premenopausal and postmenopausal age, we included both age groups. The format of focus groups was preferred over interviews because the participants should brainstorm about a novel and complex issue [28].

In 2016, participants were recruited from the research panel of the Max Planck Institute for Human Development in Berlin, Germany. Participants were contacted directly by the lab manager via a phone call. Inclusion criteria were female, German speakers, at the age of either 30-40 (premenopausal groups) or 55-65 years (postmenopausal groups). The women who consented to participate in the study were invited to one of the four focus groups ( 2 pre- and 2 postmenopausal groups), consisting of 6-7 women each. The sample was not representative, and the possibility of a selection bias must be considered as research panellists are more likely to reflect on research issues. On the other hand, this could have facilitated brainstorming about ECRA.

Altogether, 25 women between 30 and 65 years consented to participate in the study (Table 1). The two focus groups (coding: YB1YB6, YC1-YC6) at a premenopausal age ( $<40$ years) comprised 12 women with an average age of 33.5 years $(S D=2.2)$. Seven of them lived in a relationship, 2 had children, and all but 1 had statutory health insurance. The two focus groups (coding: OA1-OA7, OD1-OD6) at a

Table 1. Participants' characteristics of the four focus groups

\begin{tabular}{|c|c|c|c|c|}
\hline Group & $\begin{array}{l}\text { Age, } \\
\text { years }\end{array}$ & $\begin{array}{l}\text { Relationship } \\
\text { status }\end{array}$ & $\begin{array}{l}\text { Children, } \\
n\end{array}$ & $\begin{array}{l}\text { Health } \\
\text { insurance }\end{array}$ \\
\hline $\begin{array}{l}\text { Older A } \\
(n=7)\end{array}$ & $\begin{array}{l}55 \\
65 \\
59 \\
60 \\
61 \\
64 \\
63\end{array}$ & $\begin{array}{l}\text { single } \\
\text { single } \\
\text { single } \\
\text { single } \\
\text { partner } \\
\text { single } \\
\text { single }\end{array}$ & $\begin{array}{l}1 \\
2 \\
0 \\
0 \\
2 \\
1 \\
1\end{array}$ & $\begin{array}{l}\text { statutory } \\
\text { statutory } \\
\text { statutory } \\
\text { statutory } \\
\text { statutory } \\
\text { statutory } \\
\text { statutory }\end{array}$ \\
\hline $\begin{array}{l}\text { Younger B } \\
(n=6)\end{array}$ & $\begin{array}{l}36 \\
32 \\
37 \\
30 \\
32 \\
34\end{array}$ & $\begin{array}{l}\text { partner } \\
\text { partner } \\
\text { single } \\
\text { partner } \\
\text { single } \\
\text { partner }\end{array}$ & $\begin{array}{l}4 \\
0 \\
0 \\
0 \\
1 \\
0\end{array}$ & $\begin{array}{l}\text { statutory } \\
\text { private } \\
\text { statutory } \\
\text { statutory } \\
\text { statutory } \\
\text { statutory }\end{array}$ \\
\hline $\begin{array}{l}\text { Younger C } \\
(n=6)\end{array}$ & $\begin{array}{l}33 \\
30 \\
34 \\
35 \\
35 \\
34\end{array}$ & $\begin{array}{l}\text { single } \\
\text { single } \\
\text { partner } \\
\text { partner } \\
\text { single } \\
\text { partner }\end{array}$ & $\begin{array}{l}0 \\
0 \\
0 \\
0 \\
0 \\
0\end{array}$ & $\begin{array}{l}\text { unknown } \\
\text { statutory } \\
\text { statutory } \\
\text { statutory } \\
\text { statutory } \\
\text { statutory }\end{array}$ \\
\hline $\begin{array}{l}\text { Older D } \\
(n=6)\end{array}$ & $\begin{array}{l}63 \\
62 \\
63 \\
63 \\
63 \\
63 \\
63\end{array}$ & $\begin{array}{l}\text { partner } \\
\text { partner } \\
\text { widowed } \\
\text { single } \\
\text { partner } \\
\text { partner }\end{array}$ & $\begin{array}{l}3 \\
4 \\
1 \\
2 \\
0 \\
1\end{array}$ & $\begin{array}{l}\text { statutory } \\
\text { statutory } \\
\text { private } \\
\text { statutory } \\
\text { private } \\
\text { private }\end{array}$ \\
\hline
\end{tabular}
postmenopausal age ( $>55$ years) comprised 13 women with an average age of 61.9 years $(S D=2.6)$. Five of them lived in a relationship, 10 had children, and 10 had statutory health insurance. In the postmenopausal group, 1 woman reported having been treated for three types of cancers and losing her husband due to cancer. Another woman reported that her mother and grandmother had died from cancer. Each focus group session took about $3 \mathrm{~h}$.

\section{Data Collection}

The focus group sessions were led by the first author of the study who was trained with seminar groups. In line with the objectives of the study, a guideline for structuring the discussion of topics was developed informed by an upfront literature review that was based on the search terms "focus group" AND "genetic" AND "testing" in PubMed (3 systematic reviews, 5 clinical trials), Cochrane Library (5 trials), and TripDatabase (16 systematic reviews, 45 in primary research). Using the search terms "focus group" AND "epigenetic" AND "testing" revealed no results in November 2016. After the review, 11 studies covering the topics of lay focus groups on genetic testing [29-31] and with risk groups [32-34] were considered. Subsequently, key sections were identified and summarised. As preconceptions of the researchers about epigenetic testing and risk communication may have affected their design of the guideline, it was additionally reviewed by medical experts in that field and modified according to their feedback. Table 2 provides a summary of final key elements of the discussion guideline used for the focus group study with exemplary questions (the guideline can be found in online suppl. Table A1; for all online suppl. material, see www.karger.com/doi/10.1159/000501975)

The focus groups were videotaped. The video material was transcribed using F4 software for preparing a summarising qualitative content analysis [35].

The data were collected at the research laboratories of the Max Planck Institute for Human Development in winter 2015/2016.

\section{Analytical Strategy}

For the summarising content analysis, each distinct contribution of a speaker in the discussion was paraphrased into a respective key statement in order to shorten and generalise statements [35]. Thus, individual words, groups of words, individual sentences, or groups of sentences could be a coding unit that underlies an individual paraphrase. The paraphrases were categorised into main categories according to the key sections that guided the discussions (Table 2). Within those main categories, a coding system was built inductively by the first coder, resulting in 92 interim codes. A second coder then applied the coding system to the para- phrases independently. Inter-coder reliabilities were: Cohen's kappa $=0.72$ for "What do women want to know about epigenetic cancer risk assessment?," kappa $=0.70$ for "How do women evaluate epigenetic cancer risk assessment?," kappa $=0.58$ for risk communication (dealing with test results), and kappa $=0.65$ for risk communication (test requirements).

To improve the coding system, it was reprocessed based on coding differences. When certain differences appeared repeatedly, new codes were created bridging different interpretations of para- phrases. This reduced the number of codes substantially: for "What do women want to know about epigenetic cancer risk assessment?" from 35 down to 16, for "How do women evaluate epigenetic cancer risk assessment?" from 24 to 16, for dealing with results from 
Table 2. Key sections of the discussion guideline with explanation and example (guideline in online suppl. Table A1)

\begin{tabular}{|c|c|c|}
\hline Key section & Explanation & Example \\
\hline Introduction & $\begin{array}{l}\text { Providing women with basic } \\
\text { information about the epigenetic cancer } \\
\text { risk assessment for four female cancers, } \\
\text { yet without outlining any potentials } \\
\text { or promises }\end{array}$ & $\begin{array}{l}\text { "The test result following your } \\
\text { examination is aimed at assessing } \\
\text { your personal risk of developing } \\
\text { breast, ovarian, cervical, or } \\
\text { endometrial cancer" }\end{array}$ \\
\hline $\begin{array}{l}\text { What information do women require on } \\
\text { epigenetic cancer risk assessment? }\end{array}$ & $\begin{array}{l}\text { Discussion of information that women } \\
\text { want to receive before making testing or } \\
\text { management decisions }\end{array}$ & $\begin{array}{l}\text { "What do you want to know before } \\
\text { you can decide for or against having } \\
\text { such a test with a feeling of certainty?" }\end{array}$ \\
\hline $\begin{array}{l}\text { How do women evaluate epigenetic cancer } \\
\text { risk assessment? }\end{array}$ & $\begin{array}{l}\text { Discussion of attitudes about epigenetic } \\
\text { cancer risk assessment with an assessment } \\
\text { of perceived benefits and concerns about } \\
\text { testing }\end{array}$ & $\begin{array}{l}\text { "What do you think: Would you have } \\
\text { the test; why or why not?" }\end{array}$ \\
\hline \multirow[t]{2}{*}{$\begin{array}{l}\text { How do risks need to be communicated to } \\
\text { the women? }\end{array}$} & $\begin{array}{l}\text { Discussion of risk communication, } \\
\text { potential risk classifications and potential } \\
\text { responses to hypothetical test results, and } \\
\text { requested test performance }\end{array}$ & $\begin{array}{l}\text { "According to your understanding, } \\
\text { what is an increased risk?" }\end{array}$ \\
\hline & & $\begin{array}{l}\text { "To a certain extent, each test } \\
\text { produces false results; for instance, } \\
\text { the test could indicate a higher risk } \\
\text { than is actually the case; what do } \\
\text { you think about that?" }\end{array}$ \\
\hline
\end{tabular}

29 to 17, and for test requirements from 4 to 3 . Accordingly, with the new codes the agreement could be described as follows: kappa $=0.95$ for "What do women want to know about epigenetic cancer risk assessment?," kappa $=0.90$ for "How do women evaluate epigenetic cancer risk assessment?," kappa $=0.97$ for risk communication (dealing with test results), and kappa $=0.89$ for risk communication (test requirements). Remaining statements were categorised by the first author.

According to the qualitatively oriented text analysis which is guided by categories [36], codes were counted (with the relative frequency signalling importance) and interpreted within this final system (online suppl. Tables A2-A5) using Microsoft Excel.

\section{Results}

What Information Do Women Require on ECRA?

Knowing the baseline risk of developing cancer within a fixed time horizon was considered essential $(n=11 / 25)$. Only 3 participants under 40 years explicitly did not want to know it. Information on missing treatability was considered relevant particularly by participants under 40 years $(n=6 / 12)$, who were motivated to test for diseases with generally poor prognosis if no satisfactory treatment is available. Knowing potential benefits and harms of the test was reported to be essential $(n=3 / 12)$. Overall, how to deal with a potential result was key for many participants $(n=11 / 25)$. Furthermore, 9 participants wanted to be informed about the test quality before testing.

Information about the pathology of cancer diseases was discussed controversially: 7 participants rejected comprehensive information about disease development in advance, to avoid getting "into the whole cancer story" (Table 3). Although information about the interplay between genetic heritage, environment, behaviour, and cancer was actively requested by only 1 participant, the behavioural impact was discussed extensively, as healthy eating and exercising were considered beneficial.

Across age groups, the novelty of epigenetic compared to genetic tests was of interest $(n=11 / 25)$, as were the changes in the genome, the relation to four different types of cancer, and, most specifically, to the monitoring possibilities. Less interested in the analytical details of testing $(n=3 / 25)$, instead, 5 participants considered information on the medical procedure, the smear, and potential inferences from the imprints in epigenome relevant for their decision on testing.

When asked to imagine receiving a higher-than-aver- age risk result, the majority of women, irrespective of age 
Table 3. Exemplary quotes illustrating women's requirements for information on the ECRA

\begin{tabular}{|c|c|}
\hline Code & Selected quotes \\
\hline Analytical details & $\begin{array}{l}\text { OD3: "Why is there research that actually only tests if I, it, it or I; yeah; that's fine; } \\
\text { but we have a critical mind and ask, isn't the pharmaceutical industry perhaps } \\
\text { behind it?" }\end{array}$ \\
\hline Benefit-to-harm ratio & $\begin{array}{l}\text { YB3: "For me it would also be important (to know) if there are any kind of side } \\
\text { effects" }\end{array}$ \\
\hline Conditions & $\begin{array}{l}\text { YC5: "Who gets the data, how are the data kept, whether they're used for other } \\
\text { predictions, what kind of inferences are made?" }\end{array}$ \\
\hline Counselling & $\begin{array}{l}\text { OD2: "Counselling process. He shouldn't make the decision for me" } \\
\text { OD4: "If someone is available to talk with me, for further counselling, after ... } \\
\text { discussion of the results" }\end{array}$ \\
\hline Epigenomics in practice & $\begin{array}{l}\text { OA4: "If someone has never had a preliminary test, through a genome, how is it } \\
\text { possible? Is it something standard, where you can see what's changed; so if I don't } \\
\text { from one and the same person at the age of five or from birth on, how can I (see) } \\
\text { a change...?" } \\
\text { YB2: "Can you say, I smoked for the last } 20 \text { years and didn't do enough sports, } \\
\text { can it be stated which environmental facts might indeed have been responsible } \\
\text { that something has changed, how precisely can that be said?" }\end{array}$ \\
\hline $\begin{array}{l}\text { Genome-environment } \\
\text { interplay }\end{array}$ & $\begin{array}{l}\text { OA5: "What I already knew is that there are kinds of cancer that are closely } \\
\text { connected to my genes and are hereditary; and that there are kinds of cancer that } \\
\text { are more or less dependent on environmental influences, like my diet and my } \\
\text { etc.; is what's actually in the environment; and that's what I'd first like to be } \\
\text { informed about; I'd like to (know) about all kinds of cancer, especially how they } \\
\text { can develop; if they are connected to my genes, since in my family there've been } \\
\text { different cancers on my mother's/father's side, I always have that in mind } \\
\text { because I know that I have a lower risk because according to current research it } \\
\text { isn't inherited, that kind of information; I'd like to have that kind of information; } \\
\text { that would be really important for me" }\end{array}$ \\
\hline $\begin{array}{l}\text { High risk - follow-up } \\
\text { pipeline }\end{array}$ & $\begin{array}{l}\text { YB4: "if doctors offered routes to take" } \\
\text { YC5: "That needs to be a stepwise procedure, but not first presenting me with, } \\
\text { say, the surgical option, but instead really a stepwise, okay, like a decision tree or } \\
\text { something" } \\
\text { OA7: "I would be interested in hearing how other women dealt with it; I already } \\
\text { mentioned Angelina Jolie" } \\
\text { YB3: "If it would help if I quit [smoking] or if I ate less butter or didn't take the } \\
\text { Pill any more?" }\end{array}$ \\
\hline High risk - monitoring & $\begin{array}{l}\text { YC6: "If a positive effect occurs after, I dunno, after four weeks, or only } 20 \text { years } \\
\text { after Tve changed my life?" }\end{array}$ \\
\hline $\begin{array}{l}\text { Measures to deal with a } \\
\text { result }\end{array}$ & $\begin{array}{l}\text { OD6: "What do you do then with the information? You're told you have a high } \\
\text { risk but they don't have any plan; well, then Pd rather not know" }\end{array}$ \\
\hline Mortality and treatability & $\begin{array}{l}\text { YCA: "Because, okay, potentially, if a screening then tells me that I have cancer, } \\
\text { then it's often too late; and that's why it would make sense to know if I have an } \\
\text { increased probability; but when it's a cancer that responds relatively well to } \\
\text { treatment, then I think: well, okay, if it shows up, there's still enough that can be } \\
\text { done" }\end{array}$ \\
\hline Pathology of diseases & $\begin{array}{l}\text { YC5: "I believe that with this information package, when I think about it, it's an } \\
\text { information package from hell; that makes me..." } \\
\text { OA7: "Not me; well I don't want to know in detail which cancer now spreads and } \\
\text { how; I don't want to know. I want to know how I can prevent it from breaking } \\
\text { out; I don't want to get into the whole story of cancer, I want it to be positive" }\end{array}$ \\
\hline
\end{tabular}


Table 3 (continued)

\begin{tabular}{ll}
\hline Code & Selected quotes \\
\hline Risk category definitions & $\begin{array}{l}\text { OD3: "But then the question needs to be presented differently; what is the target } \\
\text { of such a test?... if all that comes out for us is that we have a low, medium or very } \\
\text { high risk" }\end{array}$ \\
\hline Test quality general & $\begin{array}{l}\text { (Relevance of test quality in the real world) YC5: “That's also a different thing, } \\
\text { sitting here and taking it all apart, and then sitting at the doctor's and he tells } \\
\text { you: Yes, here we can test risk as well; yes, come one, do it; if he can bill it and } \\
\text { you get along well, then pfff; go for it" }\end{array}$ \\
\hline
\end{tabular}

Participants of older age groups: OA1-OA7, OD1-OD6; participants of younger age groups: YB1-YB6, YC1YC6.

( $n=14 / 25$ ), said that they would need comprehensive information on potential follow-up actions (pipelines): surgical and non-surgical follow-up options would need to be accessible at one glance, for instance in the form of a decision tree. If this information were not available, 1 participant questioned the usefulness of receiving one's cancer risk at all. In addition, 5 women emphasised their desire for information after testing about non-invasive preventive options regarding both health care and preventive behaviour. Particularly women under 40 years $(n=$ $6 / 12$ ) requested information about risk modifications by changing smoking and diet habits orhormonal intake.

Five participants over 55 years said they would need more information on implementation of the test (e.g., how and why offered, when, by whom). Specifically, these participants were interested in how counselling (e.g., 1 participant desired a conversational forum) and educational support can be implemented. Finally, 3 participants in both age groups brought up questions of data storingand

protection, and the question of pricing $(n=2 / 25)$.

\section{How Do Women Evaluate ECRA? - Beliefs about Benefits}

ECRA found similar numbers of proponents for and against testing in each group. Over the course of discussion, the initially positive attitudes of 3 participants over 55 years turned negative.

Participants' arguments in favour of ECRA covered three major beliefs: guidance on one's individual medical strategy $(n=5 / 25)$, the development of coping strategies (empowerment) by knowing one's risks $(n=6 / 25)$, and a motivational push to healthier or more conscious living $(n=4 / 25)$. Additional beliefs were increased control of life by facing the risk $(n=3 / 25)$, a potential response to known familial cancer burden $(n=2 / 25)$, reduced concerns about getting cancer $(n=2 / 25)$, and increased survival $(n=2 / 25)$, but also pure curiosity $(n=1 / 25)$, strategic use of test results in partnership $(n=2 / 25)$, and being similar to established and accepted health tests $(n=2 / 25)$.

Five participants considered ECRA helpful for tailoring individual health care (guiding one's medical strategy). However, whereas 3 of them expressed their hopes of facilitated access to cancer screening and of maximised health care utilisation, 2 hoped to reduce it, e.g., less frequent mammography (Table 4). The additional scenario of receiving a higher-than-average risk result revealed that 12 participants would desire modified care, such as more frequent examinations, to be reassured about their health constantly. Three participants stated that they would consider prophylactic surgery in case of an unspecific higher-than-average risk result (reasons: less worrying at a later age, not before having given birth, a pragmatic solution), which excluded 2 explicitly.

Controversially, in case of a lower-than-average risk, 4 participants under 40 years and over 55 years would opt for reducing standard screening, if recommended, while 9 participants would not consider modifying individual care if covered by health insurance or if it serves to reassure.

Knowing about one's cancer risk meant $(n=6 / 25)$ : acquiring knowledge for further decisions, and thereby remaining capable of acting and developing coping strategies to deal with the disease risk. Participants who perceived that facing the risk increases control of one's personal life $(n=3 / 25)$ weighted advantages and disadvantages, e.g., not facing risk actively would be more fearful than knowing about one's risk (1 participant). Another participant, however, clearly called into question the perceived level of control.

Four participants referred to a possible motivational push by a risk result to consider how to live healthier or 
Table 4. Exemplary quotes of beliefs about benefits and concerns about testing

\begin{tabular}{|c|c|}
\hline Code & Quotes \\
\hline $\begin{array}{l}\text { Increase of subjective } \\
\text { control of life }\end{array}$ & $\begin{array}{l}\text { OD3: "That must have something to do with my attitude towards life: } \\
\text { Take advantage of opportunities, seize opportunities, keep one's eyes } \\
\text { open, keep one's ears open, be attentive, be alert, get support" } \\
\text { OD6: "Die healthy, that's the goal!" } \\
\text { YB5: "Fear of not knowing is worse, being afraid of every lump, you don't } \\
\text { get a doctor's appointment that quickly with statutory insurance; the fear } \\
\text { if much worse than when I know that I have to have close supervision" }\end{array}$ \\
\hline Guidance of medical strategy & $\begin{array}{l}\text { YB2: "For the test, it opens up the chance that you have a lower risk, that } \\
\text { you then avoid screening tests - I consider that an important reason" }\end{array}$ \\
\hline $\begin{array}{l}\text { Motivation of healthier } \\
\text { or more conscious living }\end{array}$ & $\begin{array}{l}\text { YC5: "Always this level of perceived truth, instead okay, I have it in } \\
\text { black and white, which maybe leads to some people fitting more health- } \\
\text { promoting activities somehow into their day" }\end{array}$ \\
\hline $\begin{array}{l}\text { Response to familial cancer bur- } \\
\text { den }\end{array}$ & $\begin{array}{l}\text { OD4: "I was there when she died, I was there; and the more I know the } \\
\text { better I feel" }\end{array}$ \\
\hline Strategic use & $\begin{array}{l}\text { (Woman who wants to persuade her boyfriend to have a baby at younger } \\
\text { age with her risk result) YB1: "That in any case is what he says: my mother } \\
\text { had a child at the age of } 42 \text {, and her there, Monika, Angelika at the age of } \\
44 \text {, Ursula at... So I would surely use it" }\end{array}$ \\
\hline $\begin{array}{l}\text { Aleatory uncertainty of a } \\
\text { probabilistic result }\end{array}$ & $\begin{array}{l}\text { YC1: "If I now have a higher probability, that doesn't mean that I HAVE } \\
\text { to develop it; that is, it CAN perhaps happen...” } \\
\text { YC6: "Then I'm on the safe side when I regularly have examinations by } \\
\text { the gynaecologist or umm somewhere else and I'd rather have feedback; } \\
\text { whether I'm truly healthy or sick now" }\end{array}$ \\
\hline Lack of benefits & $\begin{array}{l}\text { YB3: "Not have it done because I wouldn't be sure what I would do with } \\
\text { the increased risk" }\end{array}$ \\
\hline Unnecessary worry & $\begin{array}{l}\text { YB3: "The problem fuelling fear - increased risk doesn't mean that I will } \\
\text { get cancer but that the fear is increased" } \\
\text { YB6: "The more one worries, the worse for one's health; a positive attitude } \\
\text { is good" }\end{array}$ \\
\hline Waiting for cancer & $\begin{array}{l}\text { OD5: "Because I'll then wait for all possible signs, in a starting position: } \\
\text { Now it's happened, now the test is right, now I have cancer" }\end{array}$ \\
\hline
\end{tabular}

Participants of older age groups: OA1-OA7, OD1-OD6; participants of younger age groups: YB1-YB6, YC1-YC6.

more consciously. However, this was debated controversially: 10 participants said they would adjust their personal lifestyle if diagnosed as having a higher-than-average risk. For instance, permanent risk monitoring by repeated epigenetic testing that would reflect behavioural changes could motivate healthy behaviour $(n=5 / 25)$. However, 5 said they would not change their lifestyle, doubting that a healthy lifestyle change can be maintained over the long run. A change could at the utmost refer to more conscious living in the remaining disease- free years. In contrast, if receiving a hypothetical lower-than-average risk result, participants stated that they would take such a result as confirming that their personal lifestyle is sufficiently healthy and in no need of any behavioural adjustments.

\section{How Do Women Evaluate ECRA? - Concerns}

Unnecessary worry $(n=9 / 25)$ about cancer risk and consequences, the uncertainty surrounding the test result $(n=5 / 25)$, a perceived lack of test benefit $(n=3 / 25)$, and potential pressure to change lifestyle $(n=2 / 25)$ were concerns that were brought up against testing. Two participants over 55 years more explicitly rejected the need to know their risk of developing cancer in the future. 
Table 5. Exemplary quotes about "How to communicate risks to the women?"

\begin{tabular}{ll}
\hline Final code & Selected quotes \\
\hline Result communication & $\begin{array}{l}\text { OD2: "What would be a practical help for me would be if it was written: so and so many percent; and that } \\
\text { according to findings so far, classifications, 0-10\% is considered a low risk and then for a medium" }\end{array}$ \\
\hline Test quality & $\begin{array}{l}\text { YC5: "I find that because it has to do with probabilities, I don't have the same expectations for this test, } \\
\text { um, while one that is really a screening or where it is; it's therefore prior to that, so to say" } \\
\text { OD3: "So if you can't trust the result, how does it help me?" }\end{array}$ \\
\hline
\end{tabular}

Participants of older age groups: OA1-OA7, OD1-OD6; participants of younger age groups: YB1-YB6, YC1-YC6.

The test was not considered useful $(n=5 / 25)$ because it comes with a probabilistic result that tells nothing about whether an individual will get cancer for sure (aleatory uncertainty). Instead of having the test, 2 participants would prefer to participate in early detection. Four participants said they would not consider testing beneficial for them because they would not know how to best deal with a result showing a potentially increased risk. Nearly all participants with a negative attitude at the end of the discussion $(n=11$ out of 12) expressed the concern of unnecessary worry or an unknown level of worry by taking the test. Knowing their risk, they indicated, would reduce joy of living, increase fear and potential psychological dis- tress (in total $n=9 / 12$ ), but also give them a permanent sense of the potential onset of cancer $(n=3 / 12)$.

Moreover, given a hypothetical higher-risk result, varying feelings of perceived responsibility $(n=6 / 25)$ were anticipated: from not feeling any responsibility to experiencing guilt for risk-increasing behaviour such as smoking in the past. Participants either wanted to know about their past behaviour that could lead to cancer, if identifiable, or explicitly rejected this information. One participant under 40 years extended perceived responsibility to informing one's relatives about a higher-risk result while implying that it would be beneficial for them to be tested.

\section{How to Communicate Risks to the Women?}

Three aspects of risk communication were discussed: risk definition, test quality, and result communication. Participants from both age groups stressed that an individual's risk result of developing a certain type of cancer has to be communicated together with the risk of the respective reference group. Moreover, 17 out of 25 participants across all ages said they wanted information to be provided in the form of both single-event probabilities and defined risk categories (Table 5), which need to be reliable and meaningful by referring to behavioural and clinical implications. Nevertheless, 3 participants stressed that women's personal perceptions of risk estimates should also be considered for defining risk categories. Accordingly, participants' understanding of lower and higher risks varied remarkably. Independent of type of cancer and of time horizon and inquired in the form "relative to the average woman," participants $(n=8 / 25)$ estimated the lower-than-average risk of developing disease as being between 5 and $60 \%$ of the average population incidence and $(n=7 / 25)$ an increased risk as $40-300 \%$ higher than this incidence.

While some participants understood that the proposed test provides non-deterministic results $(n=5 / 25), 2$ were not aware of an error potential. They discussed over- and underestimation of actual risks (false-positive and falsenegative results given a risk category, respectively). Women's acceptance of both over- and underestimations of the actual cancer risk resulting from a predictive epigenetic test varied across their respective magnitudes (Fig. 1). The error potential led 6 participants to question the test altogether.

Most participants proposed test repetition as a means to increase reliability after getting a higher-than-average risk result. They were aware both that diagnoses of cancer later in life would not indicate that the test had made an underestimation error if a woman was initially diagnosed as being at low risk and that disease-free living after a high-risk diagnosis would not indicate overestimation.

Although the participants (except for 2) acknowledged that tests could not be certain, the potential level of false alarms was requested as key information mainly by the participants under 40 years, who also wanted doctors to inform them about estimation errors or potential misclassification. None of the participants showed awareness of a cumulative error potential in case of testing for multiple diseases. 
Fig. 1. Participants' acceptance of overestimation and underestimation rates.

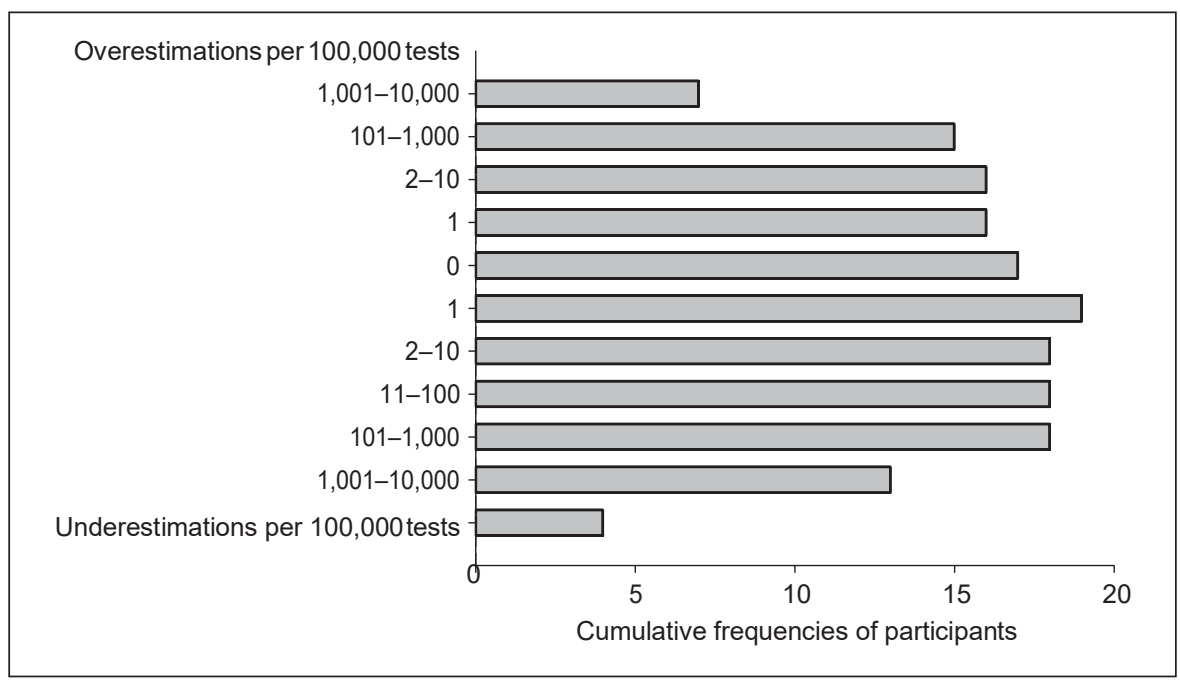

\section{Discussion}

The key finding of this study was that individual risk information was not perceived as helpful if there was no clear way to alter that risk. Women may avoid knowing their personal cancer risk if this knowledge does not necessarily imply beneficial outcomes [37], which could depend on whether risk factors can be screened for or con- trolled in other ways [38]. To enable an informed evaluation of any novel test, strategies for dealing with potential results, including medical or pharmacological risk reduction (management options) [39], useful and attainable risk-modifying behaviours (beyond general claims of healthy nutrition and regular exercise) [40] should be at the heart of health information. However, because the complex interplay of potential benefits and harms of measures varies according to individuals' baseline risks of developing diseases, risk-dependent benefit-to-harm ratios need to be assessed with both empirical evidence and modelling before health information can enable informed testing decisions.

Furthermore, understanding what is different from established genomic tests and how epigenetic change relates to the four different types of cancer appears essential to women. Given participants' worries about experiencing potential responsibility for a high-risk result that is due to past behaviour, evidence-based causal links between behavioural patterns and disease risk have to be communicated with care addressing these worries. Further, epigenetic testing can relate to behavioural control in a different way than genetic tests can because epigenetic results can be modified over time [5]. Some women believed that epigenetic risk results might enable an individual to be more proactive about her health and develop strategies to mitigate her risk because of getting feedback about one's recent behaviour when monitoring one's epigenetic modifications and related disease risks permanently or at least repeatedly.

Whereas some women anticipated modifying their lifestyle (healthier, more conscious) in the light of a high-risk result, others doubted to modify their lifestyle permanently. This corresponds with the evidence questioning whether personalised risk information leads to clinically meaningful behavioural changes [7, 8]. Health information for testing decisions could support evidence-based behavioural change in conveying the impact of risk-modifying behaviours by using risk communication standards [41]. The implications of low-risk results require separate information, as many participants were unfamiliar with the concept that "less care" might be preferable to "more care."

Participants' worries that high-risk results would induce permanent stress or anxiety that would impair their quality of life should be addressed. Similar vulnerabilities were reported for some subgroups having predictive tests on cancer susceptibility [42]. Moreover, users should be informed about potential coping strategies and support systems in advance (such as upfront counselling services).

In the light of limited understanding of medical risk information among the public, doctors [18], and geneticists, counselling on predictive testing faces additional challenges. First of all, the fact that (epi-)genetic testing contains some degree of uncertainty [43] must be incorporated in the health information users receive [44]. Most participants 
recognised the probabilistic nature of a risk estimate, though illusory beliefs in the certainty of testing are prevalent [45]. Therefore, in order to ensure users' understanding of the nature of test outcomes, information should be explicit on the issue of uncertainty and interpretability of tests results.

Furthermore, some participants stressed that test developers who aim to classify risk estimates should take into account stakeholders' perspectives about what to consider a high or a low risk. The majority of women in our study were able to express what they consider low and high-risk results. Thus, potential service users are motivated and capable of interpreting risk category definitions individually. Future investigations could provide helpful views on the task of determining thresholds that relate to meaningful clinical measures.

Moreover, test quality issues (e.g., reliability of results) [39] are of increased relevance for the multi-cancer approach, as discussed here, which included four predictions, each prone to errors. Multiple model-based risk estimates that are imprecise translate into a cumulative error potential that needs to be stressed in risk communication particularly as none of our participants showed awareness of it. The varying acceptance rates of over- and underestimation show that many women are aware of the limitations of such tests. Hence, similar to the prerequisites for informed consent in screening (e.g., informing about false positives) [46] performance of the novel test needs to be communicated transparently and comprehensibly. Communication could be supported with natural frequency trees [47], which allow the positive predictive value to be inferred prior to testing (in the case of risk categories).

The communication of test results needs to be contextualised carefully [48]: risk categories and actual risk estimates, preferably with absolute numbers [43] and reference classes as comparators [49] need to be communicated clearly, given the remarkable differences in stakeholders' perceptions of high- and low-risk categories, as found in the present study. However, risk information alone is not sufficient: delivering risk results requires appropriate information about both diseases and follow-up actions with clinical follow-up measures (e.g., early detection) [43] and risk-reducing behaviours [27] such as smoking cessation, healthy diets, or hormonal changes.

Because this study was conducted prior to the availability of the real epigenetic test, data on the test properties are not yet available and, so, the validity of our findings is limited. In the light of real performance figures, women may desire advanced information. Furthermore, we did not assess health literacy and educational levels. Although some of the women in our study never went to a university, we cannot exclude that our sample from the research panel of the Max Planck Institute for Human Development was biased towards higher literacy. As higher education is related to increased uptake of genetic counselling for hereditary cancer [50], future studies pre- ceding epigenetic testing programmes should focus on information needs of low-educated samples.

The twin goals of ECRA - to provide risk-stratified care with real benefits (precision medicine) and to motivate preventive health behaviour effectively - rely on the ability of service users to weigh benefits and harms of potential risk management options and thus to make informed testing decision. To that end, health information - about epigenetic like any other risk-predictive testing - needs to address individual information requirements regarding baseline risk, test performance, and testing consequences, and to provide transparent and balanced information on the test. However, for ECRA specifically, if one's disease risk status and behaviour are monitored over time, women do not necessarily expect to adapt their behaviour. To motivate behavioural prevention, thus, depicting links to one's behaviour is not sufficient. Evidence-based information needs to illustrate related benefits.

It remains an open question whether implementing ECRA at population level would translate into patientrelevant benefits given usual care. Groups that could benefit most from risk reduction strategies need to be identified, and randomised-controlled trials of having or not having a test with patient-relevant outcomes should be considered. When detailed insights on test performance and systematic evidence about benefit-to-harm ratios of related follow-up options are available and communicated well, the future of personalised cancer medicine can be enabled, not just foreseen.

\section{Acknowledgement}

For their support in developing the focus group guidelines, we are grateful to Ineke Bolt, Inez de Beaufort, Nora Pashayan and Martin Widschwendter.

\section{Statement of Ethics}

The study was approved by the Institutional Ethics Board of the Max Planck Institute for Human Development, Berlin, Germany. It was carried out in accordance with the guidelines and regulations of the Max Planck Society for the Advancement of Science in Germany. Informed consent was obtained from all individual participants included in the study.

Originally published in:

Public Health Genomics, 22(1-2), 2019, p. 55 


\section{Disclosure Statement}

The authors have no conflicts of interest to declare.

\section{Funding Sources}

This research is funded by the EC's Horizon 2020 research and innovation program under the grant agreement No. 634570. Furthermore, the FORECEE project is supported by The Eve Appeal. The funding organizations had no role in the design, conduct, collection, analysis, and interpretation of the data and no role in the preparation, review, or approval of the manuscript

\section{Author Contributions}

Study conceptualization and design of methodology: F.G.R., O.W.; investigation with acquisition of data: D.R., F.G.R.; formal analysis and interpretation of data: F.G.R., I.L.; writing - original draft preparation: F.G.R., D.R., I.L., O.W.; writing - review and editing: F.G.R.; supervision: O.W.; funding acquisition: O.W.

\section{References}

1 Prasad V, Lenzer J, Newman DH. Why cancer screening has never been shown to "save lives" - and what we can do about it. BMJ. 2016 Jan 6;352:h6080.

2 Khera AV, Chaffin M, Aragam KG, Haas ME, Roselli C, Choi SH, et al. Genome-wide polygenic scores for common diseases identify individuals with risk equivalent to monogenic mutations. Nat Genet. 2018 Sep;50(9):1219- 24.

3 Pashayan N, Reisel D, Widschwendter M. Integration of genetic and epigenetic markers for risk stratification: opportunities and challenges. Per Med. 2016 Mar;13(2):93-5.

4 Teschendorff AE, Gao Y, Jones A, Ruebner M, Beckmann MW, Wachter DL, et al. DNA methylation outliers in normal breast tissue identify field defects that are enriched in cancer. Nat Commun. 2016 Jan;7(1):10478.

5 Teschendorff AE, Yang Z, Wong A, Pipinikas CP, Jiao Y, Jones A, et al. Correlation of Smoking-Associated DNA Methylation Changes in Buccal Cells With DNA Methylation Changes in Epithelial Cancer. JAMA Oncol. 2015 Jul;1(4):476-85.

6 Khoury MJ, Galea S. Will Precision Medicine Improve Population Health? JAMA. 2016 Oct;316(13):1357-8.

7 Hollands GJ, French DP, Griffin SJ, Prevost AT, Sutton S, King S, et al. The impact of communicating genetic risks of disease on riskreducing health behaviour: systematic review with meta-analysis. BMJ. 2016 Mar; 352:i1102.

8 French DP, Cameron E, Benton JS, Deaton C, Harvie M. Can Communicating Personalised Disease Risk Promote Healthy Behaviour Change? A Systematic Review of Systematic Reviews. Ann Behav Med. 2017 Oct;51(5): 718-29.

9 Evidenzbasierte Medizine.V. Gute Praxis Gesundheitsinformation. Z Evid Fortbild Qual Gesundhwes. 2016;110:85-92.

10 Shofer S, Beyea M, Li S, Bastian LA, Wahidi MM, Kelley M, et al. Feasibility of using an epigenetic marker of risk for lung cancer, methylation of p16, to promote smoking cessation among US veterans. BMJ Open Respir Res. 2014 Jun;1(1):e000032.

11 Marteau TM, Weinman J. Self-regulation and the behavioural response to DNA risk information: a theoretical analysis and framework for future research. Soc Sci Med. 2006 Mar; 62(6):1360-8.

12 Dent T, Jbilou J, Rafi I, Segnan N, Törnberg S, Chowdhury S, et al. Stratified cancer screening: the practicalities of implementation. Public Health Genomics. 2013;16(3):94-9.

13 Hall AE, Chowdhury S, Hallowell N, Pashayan N, Dent T, Pharoah P, et al. Implementing risk-stratified screening for common cancers: a review of potential ethical, legal and social issues. J Public Health (Oxf). 2014 Jun;36(2):285-91.

14 Shieh Y, Eklund M, Sawaya GF, Black WC, Kramer BS, Esserman LJ. Population-based screening for cancer: hope and hype. Nat Rev Clin Oncol. 2016 Sep;13(9):550-65.

15 Trivers KF, Baldwin LM, Miller JW, Mat- thews B, Andrilla CH, Lishner DM, et al. Re- ported referral for genetic counseling or BRCA $1 / 2$ testing among United States physicians: a vignette-based study. Cancer. 2011 Dec;117(23):5334-43.

16 Forbes LJ, Ramirez AJ; Expert group on Information about Breast Screening. Offering in- formed choice about breast screening. $\mathrm{J}$ Med Screen. 2014 Dec;21(4):194-200.

17 Calsbeek H, Morren M, Bensing J, Rijken M. Knowledge and attitudes towards genetic testing: a two year follow-up study in patients with asthma, diabetes mellitus and cardiovascular disease. J Genet Couns. 2007 Aug;16(4): 493-504.

18 Wegwarth O, Schwartz LM, Woloshin S, Gaissmaier W, Gigerenzer G. Do physicians understand cancer screening statistics? A national survey of primary care physicians in the United States. Ann Intern Med. 2012 Mar; 156(5):340-9.

19 Wegwarth O, Gaissmaier W, Gigerenzer G. Deceiving numbers: survival rates and their impact on doctors' risk communication. Med Decis Making. 2011 May-Jun;31(3):386-94.

20 Wegwarth O, Gigerenzer G. US gynecologists' estimates and beliefs regarding ovarian cancer screening's effectiveness 5 years after release of the PLCO evidence. Sci Rep. 2018 Nov;8(1):17181.

21 Wegwarth O, Gigerenzer G. "There is nothing to worry about": gynecologists' counseling on mammography. Patient Educ Couns. 2011 Aug;84(2):251-6.

22 Studdert DM, Mello MM, Sage WM, DesRoches CM, Peugh J, Zapert K, et al. Defensive medicine among high-risk specialist physicians in a volatile malpractice environment. JAMA. 2005 Jun;293(21):2609-17.

23 Lieb K, Brandtönies S. A survey of german physicians in private practice about contacts with pharmaceutical sales representatives. Dtsch Arztebl Int. 2010 Jun;107(22): 392-8.

Originally published in:

Public Health Genomics, 22(1-2), 2019, p. 56 
24 Prinz R, Feufel MA, Gigerenzer G, Wegwarth O. What counselors tell low-risk clients about HIV test performance. Curr HIV Res. 2015; 13(5):369-80.

25 Pieterse AH, Ausems MG, Van Dulmen AM, Beemer FA, Bensing JM. Initial cancer genetic counseling consultation: change in counselees' cognitions and anxiety, and association with addressing their needs and preferences. Am J Med Genet A. 2005 Aug;137(1):27-35.

26 Mesters I, Ausems A, De Vries H. General public's knowledge, interest and information needs related to genetic cancer: an exploratory study. Eur J Cancer Prev. 2005 Feb;14(1): 69-75.

27 Lautenbach DM, Christensen KD, Sparks JA, Green RC. Communicating genetic risk in- formation for common disorders in the era of genomic medicine. Annu Rev Genomics Hum Genet. 2013;14(1):491-513.

28 Powell RA, Single HM. Focus groups. Int J Qual Health Care. 1996 Oct;8(5):499-504.

29 Lipstein EA, Nabi E, Perrin JM, Luff D, Browning MF, Kuhlthau KA. Parents' decision-making in newborn screening: opinions, choices, and information needs. Pediatrics. 2010 Oct;126(4):696-704.

30 Pivetti M, Montali L, Simonetti G. The discourse around usefulness, morality, risk and trust: a focus group study on prenatal genetic testing. Prenat Diagn. 2012Dec;32(12):1205-11.

31 Vuckovic N, Harris EL, Valanis B, Stewart B. Consumer knowledge and opinions of genetic testing for breast cancer risk. Am J Obstet Gynecol. 2003 Oct;189(4 Suppl):S48-53.

32 Mellon S, Gauthier J, Cichon M, Hammad A, Simon MS. Knowledge, attitudes, and beliefs of Arab-American women regarding inherited cancer risk. J Genet Couns. 2013 Apr; 22(2):268-76.

33 Rahman B, Meisel SF, Fraser L, Side L, Gessler S, Wardle J, et al. Population-based genetic risk prediction and stratification for ovarian cancer: views from women at high risk. Fam Cancer. 2015 Mar;14(1):135-44.

34 Sheppard VB, Graves KD, Christopher J, Hurtado-de-Mendoza A, Talley C, Williams KP. African American women's limited knowledge and experiences with genetic counseling for hereditary breast cancer. J Genet Couns. 2014 Jun;23(3):311-22.

35 Flick U. Qualitative Sozialforschung - Eine Einführung, vollständig überarbeitete und erweiterte Neuausgabe. Reinbek bei Hamburg: Rowohlt; 2007.

36 Mayring P, Fenzl T. Qualitative Inhaltsanalyse. In: Baur N, Blasius J, editors. Handbuch Methoden der empirischen Sozialforschung. Wiesbaden: Springer Fachmedien Wiesbaden; 2014. pp. 543-56.

37 Emanuel AS, Kiviniemi MT, Howell JL, Hay JL, Waters EA, Orom H, et al. Avoiding cancer risk information. Soc Sci Med. 2015 Dec; $147: 113-$ 20.

38 Melnyk D, Shepperd JA. Avoiding risk information about breast cancer. Ann Behav Med. 2012 Oct;44(2):216-24.

39 Bernhardt BA, Geller G, Strauss M, Helzlsouer KJ, Stefanek M, Wilcox PM, et al. Toward a model informed consent process for BRCA1 testing: a qualitative assessment of women's attitudes. J Genet Couns. 1997 Jun;6(2):207-22.

40 Silk KJ, Bigbsy E, Volkman J, Kingsley C, At- kin C, Ferrara M, et al. Formative research on adolescent and adult perceptions of risk factors for breast cancer. Soc Sci Med. 2006 Dec; 63(12):3124-36.

41 IPDAS-Collaboration. IPDAS-Checklist for Judging the Quality of Patient Decision Aids. http://ipdas.ohri.ca/IPDAS_checklist.pdf, 2005, 2017

42 Croyle RT, Smith KR, Botkin JR, Baty B, Nash J. Psychological responses to BRCA1 mutation testing: preliminary findings. Health Psychol. 1997 Jan;16(1):63-72.

43 Bottorff JL, Ratner PA, Johnson JL, Lovato CY, Joab SA. Communicating cancer risk information: the challenges of uncertainty. Patient Educ Couns. 1998 Jan;33(1):67-81.

44 Hunter DJ. Uncertainty in the Era of Precision Medicine. N Engl J Med. 2016 Aug; 375(8):711-3.

45 Gigerenzer G. Risk savvy: How to make good decisions. New York: Penguin; 2015.

46 Hersch J, Barratt A, Jansen J, Irwig L, Mc- Geechan K, Jacklyn G, et al. Use of a decision aid including information on overdetection to support informed choice about breast cancer screening: a randomised con- trolled trial. Lancet. 2015 Apr;385(9978): 1642-52.

47 Gigerenzer G. What are natural frequencies? BMJ. 2011 Oct 17;343:d6386.

48 O'Doherty K, Suthers GK. Risky communication: pitfalls in counseling about risk, and how to avoid them. J Genet Couns. 2007 Aug; 16(4):409-17.

49 Fagerlin A, Zikmund-Fisher BJ, Ubel PA. "If I'm better than average, then I'm ok?": comparative information influences beliefs about risk and benefits. Patient Educ Couns. 2007 Dec;69(1-3):140-4.

50 Willis AM, Smith SK, Meiser B, Ballinger ML, Thomas DM, Young MA. Sociodemographic, psychosocial and clinical factors associated with uptake of genetic counselling for hereditary cancer: a systematic review. Clin Genet. 2017 Aug;92(2):121-33. 